\title{
BIOFUELS FOR TRANSPORTATION
}

Global Potential and Implications for Sustainable Agriculture and Energy in the 21st Century

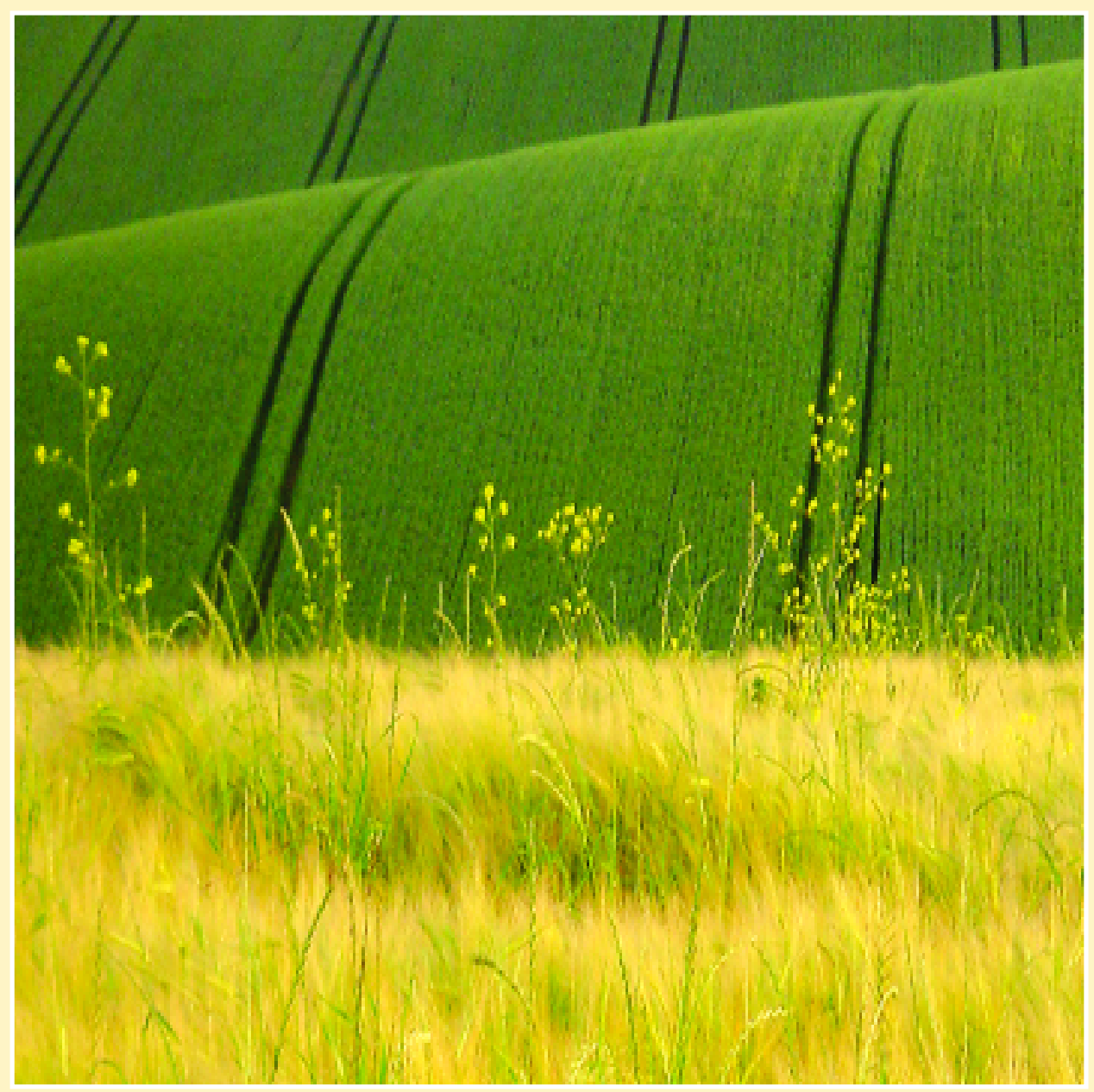

- Summary June 2006 


\section{Acknowledgments}

\section{Sponsor}

German Federal Ministry of Food, Agriculture and Consumer Protection (BMELV)

Collaborating Agencies

German Agency for Technical Cooperation (GTZ)

German Agency of Renewable Resources (FNR)

Producer and Publisher

Worldwatch Institute

Lisa Mastny, Editor

Project Manager

Suzanne C. Hunt, Worldwatch Institute

\section{Lead Researchers and Contributors}

Jim Easterly, Easterly Consulting

Andre Faaij, Utrecht University

Christopher Flavin, Worldwatch Institute

Ladeene Freimuth, Freimuth Consulting

Uwe Fritsche, Öko-Institut

Mark Laser, Dartmouth College

Lee Lynd, Dartmouth College

Jose Moreira, Brazilian Reference Center on Biomass

Sergio Pacca, University of São Paulo

Janet L. Sawin, Worldwatch Institute

Lauren Sorkin, Worldwatch Institute

Peter Stair, Worldwatch Institute

Alfred Szwarc, ADS Technology and Sustainable Development

Sergio Trindade, SE2T International, Ltd.

Other Contributors: Thanks to the following people for contributing time, materials, and/or review comments: Don Abraham (Social Technologies); Clayton Adams; Carsten Agert (Fraunhofer-Institut für Solare Energiesysteme); Weber Amaral (Brazilian Biofuels Programme); Robert Anex (lowa State University); Eliana Antoneli (Brazilian Biofuels Programme); Daniel Aronson (Petrobras); Dirk Assmann (GTZ); Sergio Barros (U.S. Department of Agriculture-USDA); Christoph Berg (F.O. Licht); Göran Berndes (Chalmers University of Technology); Davis Bookhart (Charm21); Barbara Bramble (National Wildlife Federation-NWF); Thomas Breuer (University of Bonn); Steve Brisby (California Air Resources Board); Neil Brown (U.S. Senate Committee on Foreign Relations); Robert Brown (lowa State Bioeconomy Initiative); William Burnquist (Centro de Tecnologia Copersucar-CTC); Heloisa Burnquist (University of São Paulo); Jake Caldwell (Center for American Progress); Matt Carr (Biotechnology Industry OrganizationBIO); Eduardo Carvalho (União da Agroindústria Canavieira de São Paulo-UNICA); Frank Casey (Defenders of Wildlife); Christine Clashausen (GTZ); Suani Teixeira Coelho (Regional Government of São Paolo); Ana Unruh Cohen (Center for American Progress); Daniel de La Torre Ugarte (University of Tennessee); Aimee Delach (Defenders of Wildlife); Mark A. Delucchi (University of California, Davis); Neeraj Doshi (Tufts Fletcher School of Law and Diplomacy); Reid Detchon (Energy Future Coalition); Brent Erickson (BIO); Emanuel Filho (Petrobras); Elke Foerster (GTZ); Hilary French (Worldwatch Institute); Lew Fulton (U.N. Environment Programme); Rubens Gama (Brazilian Embassy); Jana Gastellum (Energy Future Coalition); Simon Godwin (DaimlerChrysler); Alex Goyes (International Food \& Agricultural Trade Policy Council-IPC); Nathanael Greene (Natural Resources Defense Council-NRDC); Ralph Groschen (Minnesota Department of Agriculture); Kathleen Hadley (National Center for Appropriate Technology); Brian Halweil (Worldwatch Institute); Charlotte Hebebrand (IPC); Russel Heisner (BC International); Jan Henke (Institute for World Economics); Christian Henkes (GTZ); Chris Herman (U.S. Environmental Protection Agency); Bill Holmberg (American Council on Renewable Energy); Monique Hoogwijk (Ecofys); Rob Howse (University of Michigan); Roland Hwang (NRDC); Paul Joffe (NWF); Francis Johnson (Stockholm Environment Institute); John Karhnak (Raytheon UTD); Dennis Keeney (Institute for Agriculture and Trade Policy-IATP); Birger Kerckow (FNR); Jim Kleinschmidt (IATP); Ricardo Külheim (GTZ); Regis Verde Leal (University of Campinas); Deron Lovaas (NRDC); Warren Mabee (International Energy Agency-IEA); James Martin (Omnitech International); Joseph Mead (World Energy Alternatives); Rogerio Miranda (Winrock International); Ian Monroe (Winrock International); David Morris (Institute of Local Self-Reliance); Danielle Nierenberg (Worldwatch Institute); Peter O'Connor; Leslie Parker (Renewable Energy and International Law Project); Sillas Oliva Filho (Petrobras); Luiz Prado (LaGuardia Foundation); Luke Pustevjosky (Fieldstone Private Capital Group); Guido Reinhardt (IFEU Institute); Michael Renner (Worldwatch Institute); Fernando Ribeiro (São Paulo Sugar Cane Agroindustry Union); Thereza Rochelle (Brazilian Biofuels Programme); Rodrigo Rodrigues (Brazilian Ministry of Agriculture); Ian Monroe (Winrock International); Friederike Rother (GTZ); Katja Rottmann (Worldwatch Institute); Larry Russo (U.S. Department of Energy); Liane Schalatek (Heinrich Böll Foundation); Hosein Shapouri (USDA); Ralph Simms (Massey University); Edward Smeets (Utrecht University); Ron Steenblik (International Institute for Sustainable Development); Steve Suppan (IATP); Freyr Sverrisson (Energy Consultant); Holger Thamm (Office of Angelika Brunkhorst, Member of German Parliament); Ibrahim Togola (Mali-Folkecenter); Boris Utria (World Bank); Friedrich Wacker (German Embassy); Michael Wang (Argonne National Laboratory); David Waskow (Friends of the Earth); Carol Werner (Environmental and Energy Study Institute); Jetta Wong (Environmental and Energy Study Institute). 


\section{BIOFUELS FOR TRANSPORTATION}

\section{A Booming Industry}

The world is on the verge of unprecedented growth in the production and use of biofuels (liquid fuels derived from plants and other biomass). Rising oil prices, national security concerns, the desire to increase farm incomes, and a host of new and improved technologies are propelling many governments to enact powerful incentives for the production and use of these fuels. This, in turn, is sparking a large new wave of investment.

The two most prevalent biofuels are ethanol, currently produced from sugar or starch crops, and biodiesel, produced from vegetable oils or animal fats. World production of ethanol more than doubled between 2000 and 2005, while production of biodiesel quadrupled. (See Figures 1 and 2.) In 2005 alone, ethanol production rose 19 percent and biodiesel production jumped 60 percent (starting from a much smaller base). In total, biofuels now provide 1 percent of the world's liquid transport fuels.

Brazil and the United States together account for 90 percent of the world's fuel ethanol production, thanks to strong government support that began in the 1970s. (See Table 1.) In Brazil, ethanol derived from sugar cane claims 40 percent of the light fuels market and has helped the country end its dependence on imported oil. In the much larger U.S. fuels market, ethanol derived mainly from corn now makes up 2 percent of the total light fuel supply. The European Union, and Germany in particular, dominates world biodiesel production and use. (See Table 2.)

As oil prices and environmental concerns have risen in the past few years, investment in new biofuel facilities has mushroomed in Brazil, Europe, the United States, and elsewhere. Among the countries that have made major commitments to biofuels in recent years are China, Colombia, India, the Philippines, and Thailand. The Swedish government has vowed to end the country's dependence on fossil fuels by 2020 , with biofuels slated to play a major role.

Among the companies that have announced significant new investments in biofuels are Archer Daniels Midland, Cargill, DaimlerChrysler, Dupont, and Shell. Major investors in biofuels include Richard Branson, Bill Gates, Vinod Khosla, and most recently, the global investment firm Goldman Sachs. And several leading automakers, including Ford, General Motors, and Volkswagen, have announced plans to dramatically increase
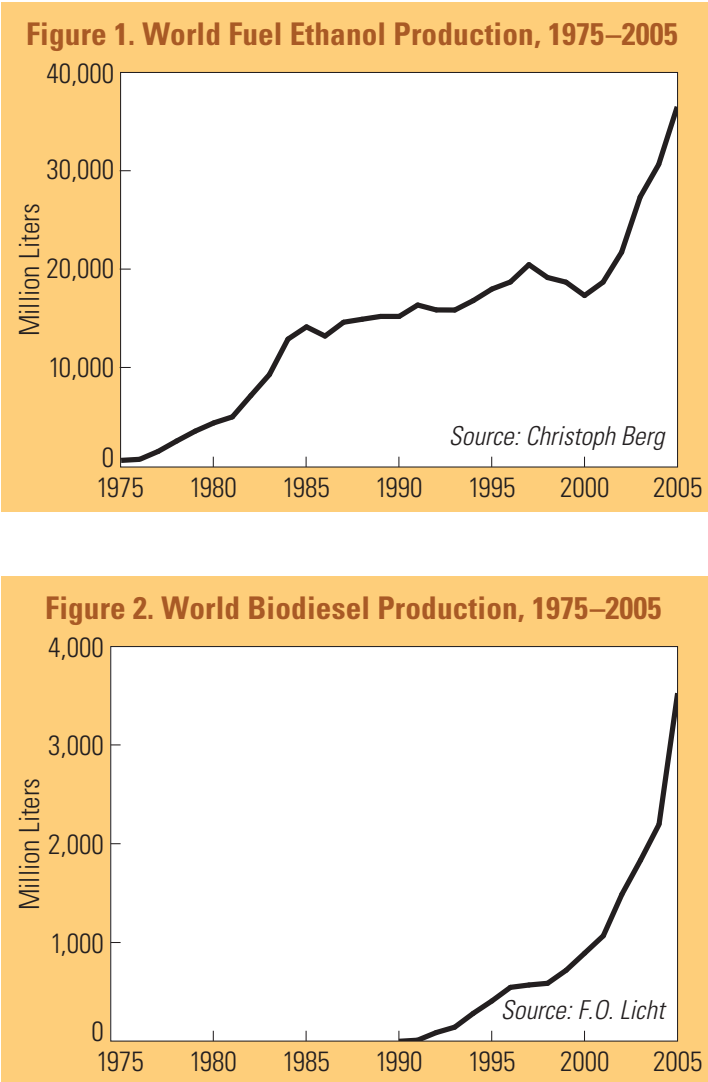
production of flexi-

ble-fuel vehicles that can run on varying blends of ethanol and gasoline.

\section{The Promise of New Technologies}

Biofuel production has become substantially more efficient over the last 25 years as Brazil and the 
Table 1. Top Five

Fuel Ethanol Producers in 2005

\begin{tabular}{lr}
\hline & (million liters) \\
Brazil & 16,500 \\
United States & 16,230 \\
China & 2,000 \\
European Union & 950 \\
India & 300 \\
\hline Source: Christoph Berg &
\end{tabular}

Table 2. Top Five

Biodiesel Producers in 2005

(million liters)

France $\quad 511$

United States 290

Italy 227

Austria

83

Source: F. 0. Licht
Germany $\quad 1,920$

United States have scaled up their industries. In the U.S., ethanol from corn is now competitive with gasoline, while in Brazil sugar cane ethanol is far less expensive than gasoline. (See Figure 3.) Such incremental gains are likely to continue for years to come. However, the greatest potential for biofuels lies in the development of new technologies that will significantly expand the range of biomass feedstock, increase conversion efficiencies, and lower production costs.

One of the innovations expected to dramatically boost biofuel production is the ability to generate the fuels from cellulosic materials such as plant stalks, leaves, and wood. This includes producing ethanol through the use of enzymes, and synthetic diesel via a gasification/FischerTropsch process pioneered in Germany and South Africa. These technologies, which are still relatively expensive, are close to being introduced commercially and will make it possible to create liquid fuels from agricultural, municipal, and forestry wastes, as well as from non-food perennial

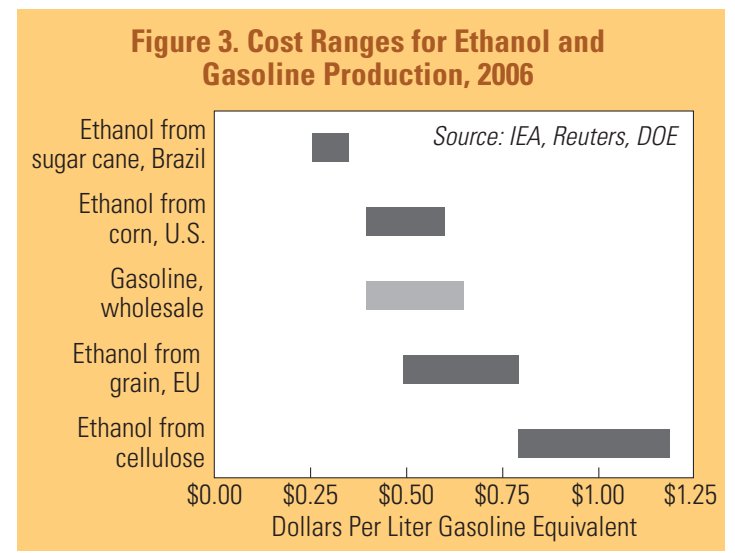

crops such as switchgrass that can be grown on degraded lands with modest water and fertilizer requirements.

New biofuel technologies have attracted substantial government R\&D investment and are now becoming a

hot investment area for the venture capital community in Silicon Valley and beyond. As a result, technological progress is likely to accelerate in the years immediately ahead.

\section{How Large is the Potential?}

Policymakers around the world are asking how large a share of the world's liquid fuel supply can be provided by biofuels. While no definitive answer is yet possible, there is no doubt that these fuels could potentially account for a significant share of total fuel use. If combined with greatly increased vehicle fuel economy, strengthened public transportation, and new automotive technologies such as plug-in hybrids, biofuels can play a central role in building a sustainable transportation sector.

A recent joint study by the U.S. Departments of Agriculture and Energy found that advanced biofuels could substitute for 37 percent of U.S. transport fuel use within the next 25 years, with the figure rising to 75 percent if vehicle fuel economy is doubled. The biofuel potential in Europe is estimated to be in the range of 20-25 percent, even assuming that strict sustainability criteria are used for land use and crop choice and that bioenergy use in non-transport sectors grows in parallel. Many small developing countries with favorable growing climates could likely meet all of their liquid fuel needs with biofuels.

The yields of currently used biofuel feedstock vary widely. (See Figure 4.) The efficiency of the conversion process and the availability of suitable land and water resources for biofuel production will be the primary limitations to the future contribution of these fuels. Among the potential challenges that will need to be addressed as markets expand are growing competition for land and water resources, aquifer depletion, soil erosion, and the loss of biologically rich ecosystems, including tropical forests. Policymakers will also need to keep an eye on the potential for biofuels to drive up food prices, a trend that could be beneficial to farmers but could also make it more difficult to meet the food needs of the urban poor.

\section{How "Green" Are Biofuels?}

One of the great promises of biofuels is their potential to provide an environmentally sustainable alternative to the petroleum fuels that have exacted such a heavy toll on the planet. Biofuels do have the ability to reduce pollution, but they can also exacerbate a range of other environmental problems if not developed carefully.

Biofuels are essentially a way to convert solar energy into liquid form via photosynthesis. One of the greatest concerns raised about them, however, is their net energy balance-i.e., whether production of the fuels requires more energy inputs (particularly fossil energy, in the form of fertilizers, tractor fuel, processing energy, etc.) than is ultimately contained in the biofuels themselves. Advances in technology have improved production efficiency, giving all current 
biofuels a positive fossil energy balance. (See Table 3.) Not only is the efficiency of the conversion process advancing steadily, but bioenergy is increasingly being used for feedstock processing as well. Both approaches reduce the amount of fossil fuels used to convert crops into biofuels.

Transportation is responsible for 25 percent of the world's greenhouse gas (GHG) emissions, and this share is rising. Biofuels have the potential to significantly reduce GHG emissions, particularly with the development of advanced biomass technologies that rely on agricultural wastes and cellulosic crops such as switchgrass. (See Figure 5.) If cultivated in the right way, these crops can actually sequester carbon in the soil, helping to reduce the amount in the atmosphere. However, if biofuels are produced from low-yielding crops, grown with heavy inputs of fossil energy on previously wild grasslands or forests, and/or processed into fuel using fossil energy, they have the potential to generate as much or more GHG emissions than petroleum fuels do.

Blending biofuels with petroleum fuels generally brings a reduction in vehicle emissions of sulfur, particulates, and carbon monoxide. In developing countries, ethanol and biodiesel could play a significant role in improving urban air quality and helping to phase out lead-based and otherwise toxic fuel additives.

One of the risks of biofuels is the potential for fuel crops to be grown on ecologically fragile lands, accelerating soil erosion and the depletion of aquifers. In addition, biofuel crops could destroy some of the world's remaining tropical ecosystems, home to vast treasures of biodiversity. Ecologists point with alarm to the massive Brazilian soybean crop that is encroaching on the outer fringes of the Amazon Basin. While most of this crop is currently used as cattle feed, soybeans are considered a significant potential biodiesel source. Large-scale use of palm oil, the most economical feedstock for biodiesel today, could lead to similar problems: tropical forests in southeast Asia have already been cleared to make room for palm plantations, mainly as a source for cooking oil.

Once technology allows for more widespread production of biofuels from grasses and trees, these perennial crops could be used to protect lands that are vulnerable to erosion and to restore lands degraded by grazing. For such benefits to be realized, the expansion of biofuel production will need to be accompanied by a new generation of strict land-use laws, particularly in countries with tropical forests that are at risk of destruction.

The experience of the world's leading biofuel producers has shown that in the absence of strong, wellimplemented policies, environmental degradation and social conflicts can result. Governmental policy decisions, and the resolve to see them properly enacted, are therefore critical in determining the net ecological impacts of biofuels.

\section{A New Future for Rural Communities?}

Another promise of biofuels-and one of the main political engines behind them-is their potential to increase farm incomes and strengthen rural economies. The ability to grow energy crops in addition to food and fiber crops could transform agriculture more profoundly than any development since the green revolution.

The dispersed nature of agriculture makes it unlikely that biofuel production will become as cen-

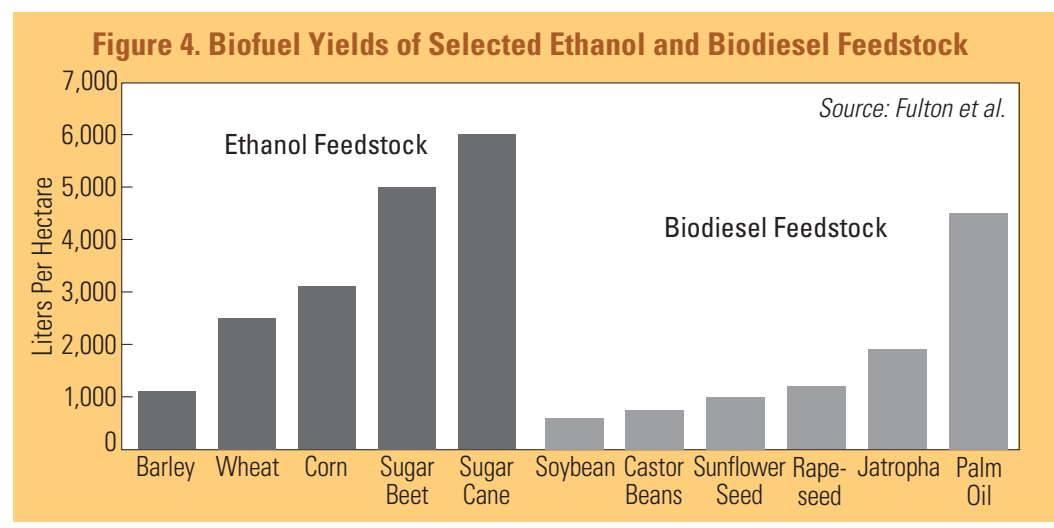

tralized as the oil industry. However, as biofuels become a major commodity, larger farms and agribusinesses will play a growing role. Agricultural resources are unevenly distributed in many countries, and the ability of small farmers to benefit from bio- 


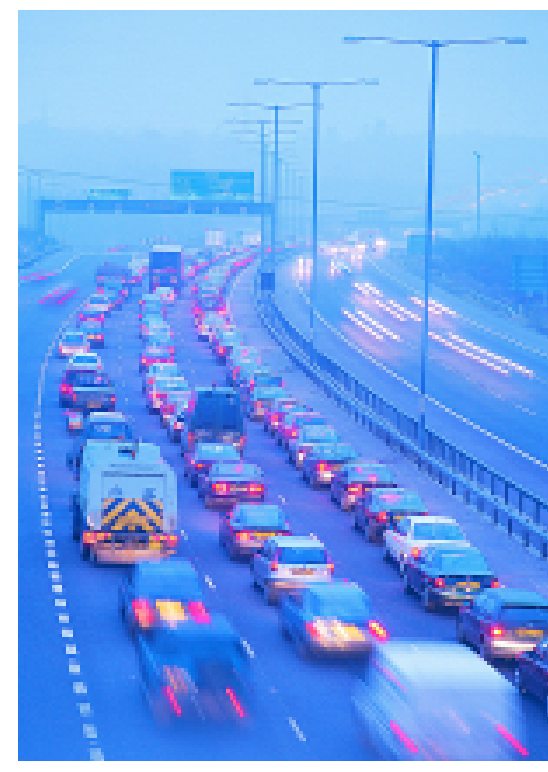

The global transport sector generates onequarter of the world's energy-related greenhouse gases. fuels will be determined in part by broader decisions about land reform and tax policies. If smaller-scale production is to be nurtured as a way of distributing the economic benefits of biofuels, government policies will be needed to encourage this.

The production of biofuels has already begun to affect agricultural commodity markets. About 50 percent of Brazil's sugar cane crop was dedicated to producing ethanol in 2005, and this demand has helped drive up the price of sugar worldwide. In the United States, an estimated 15 percent of the corn crop was used to produce ethanol in 2005, and in 2006 the volume of corn used for ethanol is expected to equal total U.S. corn exports. In the European Union, more than 20 percent of the rape-

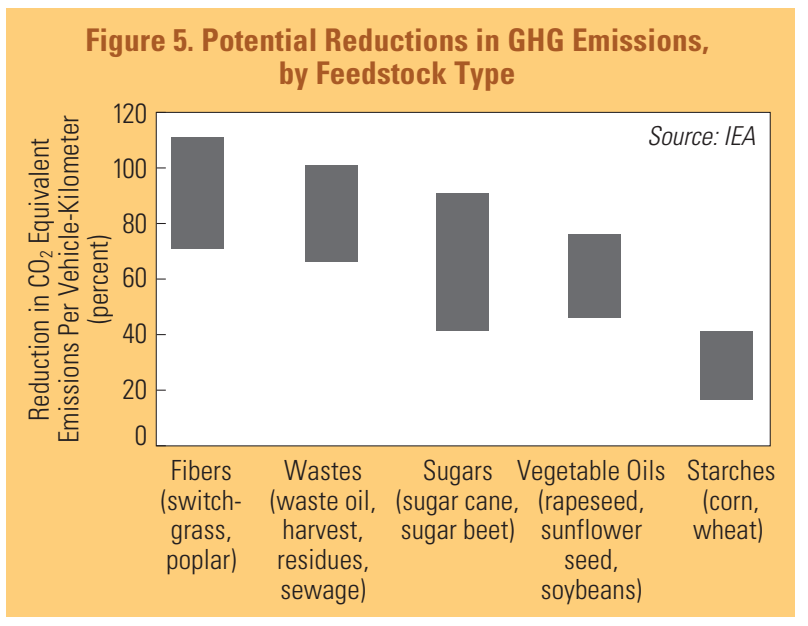

seed crop was tapped to provide about 1 percent of EU transport fuel in the form of biodiesel in 2005.

As a refined product, biofuels can add value to raw agricultural goods. The biofuel industry has already become an engine of economic development and job creation in south-central Brazil and the U.S. Midwest. The ethanol industry is credited with directly providing nearly 200,000 jobs in the United States and half a million jobs in Brazil. These benefits are now likely to spread internationally, with the greatest impact occurring in agriculturally based economies with favorable conditions for growing biofuel crops. How widely the benefits are shared will depend in part on whether farmers and producers of forestry materials own portions of the biofuel processing and distribution industry (e.g. via co-ops or other ownership structures). Re-circulating biofuel revenues in the local economy can maximize the economic benefits of shifting away from imported fuels.

In countries and regions where access to modern forms of energy is limited or absent, government and development agency support for small-scale biofuel production can help provide clean, accessible energy that is vital for rural development and poverty alleviation, helping to achieve the United Nations' Millennium Development Goals.

\section{Energy Security and Trade}

The world's current transportation systems are highly dependent on petroleum, a resource that is concentrated in relatively few countries. This has left the global economy at risk of disruption, particularly with oil supplies as tight as they are now. Biofuels promise to bring a much broader group of countries into the liquid fuel business, diversifying supplies and reducing the risk of disruption. And because biofuels can be produced in most regions of the globe, the risks inherent in transporting fuel over long distances will also be reduced.

Of the world's 47 poorest countries, 38 are net oil importers, and 25 of these import all of their oil. In many smaller and poorer nations, 90 percent or more of the total energy used comes from imported fossil fuels. In some cases, a large share of the foreign exchange earnings goes to pay for oil, and much of the government revenue is used to subsidize kerosene and diesel fuel. Yet many of these same countries have substantial agricultural bases and are well suited to growing sugar cane, palm oil, and other highly productive energy crops. Some of these countries even have the potential to become net exporters of liquid fuels.

International trade in biofuels is currently limited by the fact that many countries maintain tariffs on these fuels, both to protect their domestic industries and to assure that their substantial domestic subsidies are not used to support the industries of other nations. (See Figure 6.) This is likely to change in the years ahead. Many of the rich countries that consume large quantities of transportation fuels (in Europe and Japan, for example) have limited land available for 
growing biomass feedstock, which leaves them unable to generate more than a fraction of their transportation fuels from domestically produced biofuels.

Some countries may decide to eliminate biofuel tariffs on a bilateral basis with individual trading partners. The United States, for example, already allows the preferential import of ethanol from the Caribbean. And Sweden has indicated that it wants to encourage large-scale biofuel imports. Ongoing negotiations at the World Trade Organization, aimed at liberalizing trade in agricultural commodities, are expected to address the potential for reducing biofuel trade barriers, offering an opportunity for countries to generate new agricultural revenue streams to offset the loss of trade-distorting subsidies.

\section{Policy Recommendations}

For biofuels to make a large and sustainable contribution to the world energy economy, governments will need to enact consistent, long-range, and coordinated policies that are informed by broad stakeholder participation. Policy priorities include:

- Strengthen the Market. Biofuel policies should focus on market development, creating an enabling environment based on sound fiscal policy and support for private investment, infrastructure development, and the building of transportation fleets that are able to use the new fuels.

\section{- Speed the Transition to Next-Generation}

Technologies. Policies are needed to expedite the transition to the next generation of feedstock and technologies that will enable dramatically increased production at lower cost, while reducing negative environmental impacts.

- Protect the Resource Base. Maintaining soil productivity, water quality, and myriad other ecosystem services is essential. National and international environmental sustainability principles and certification systems are important for protecting resources as well as maintaining public trust in the merits of biofuels.

- Encourage Broad Rural Economic Benefits. Government fiscal and land use policies will help determine how broadly the economic revenues from biofuels are spread and how they will shape rural economies.

- Facilitate Sustainable International Biofuel Trade. Continued rapid growth of biofuels will require the development of a true international market in these fuels, unimpeded

by the trade

restrictions in

place today. Freer

movement of bio-

fuels around the

world should be

coupled with social

and environmental

standards and a

credible system to

certify compliance.

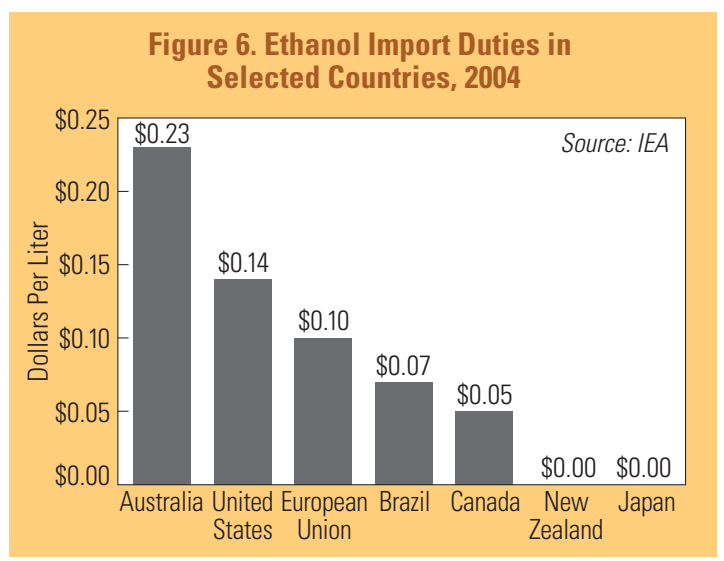

- Efficiency and

Improved Public Transport. Biofuels should be

developed within the context of a broad transfor-

mation of the transport sector aimed at dramatical-

ly improving transport efficiency.

Supportive government policies have been essential to the development of modern biofuels over the past two decades.

Countries seeking to develop domestic biofuel industries will be able to draw important lessonsboth positive and negative-from the industry pioneers: Brazil, the United States, and the European Union. Among the success-

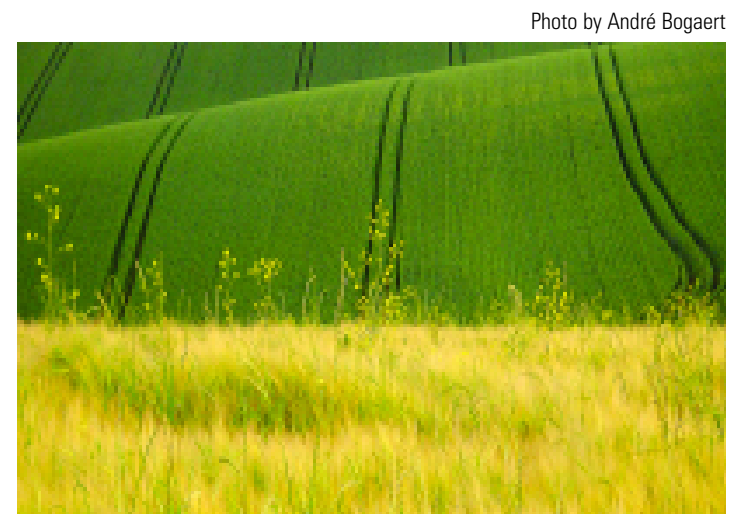

Biofuels could transform agriculture more profoundly than any development since the green revolution. ful policies that have

fostered biofuel production and use are:

- Blending Mandates

- Tax Incentives

- Government Purchasing Policies

- Support for Biofuel-Compatible Infrastructure and Technologies

- RD\&D (including crop research, conversion technology development, feedstock handling, etc.)

- Public Education and Outreach

- Reduction of Counterproductive Subsidies

- Investment Risk Reduction for Next-Generation Facilities

- Gradual Reduction of Supports as the Market

Matures 
Biofuels for Transportation: Global Potential and Implications for Sustainable Agriculture and Energy in the 21st Century was produced by the Worldwatch Institute and the German Agency for Technical Cooperation (GTZ), with funding from the German Federal Ministry of Consumer Protection, Food and Agriculture (BMELV). The findings and recommendations are based on the work of an international, interdisciplinary team of researchers, building on the input from detailed country studies carried out by the GTZ in Brazil, China, India, and Tanzania, and do not necessarily reflect the views of the Ministry.

\title{
To download a longer summary of the report, visit www.worldwatch.org/pubs/biofuels.
}

\author{
Contacts: \\ Suzanne Hunt \\ Worldwatch Institute \\ 1776 Massachusetts Avenue, N.W. \\ Washington, DC 20036-1904 \\ U.S.A. \\ Tel: (+1) 202.452.1992, ext. 541 \\ Fax: (+1) 202.833.0377 \\ E-mail: shunt@worldwatch.org \\ Elke Förster \\ Deutsche Gesellschaft für Technische Zusammenarbeit (GTZ) GmbH \\ Dag-Hammarskjöld-Weg 1-5 \\ 65760 Eschborn \\ Germany
}

Tel: (+49) 6196791424

Fax: (+49) 6196796103 